\title{
Technology transfer, FDI and economic growth in the ASEAN region
}

\begin{abstract}
The aim of this study was to investigate the intensity of international technology transfer in selected ASEAN economies through import of machinery and foreign direct investment. The technology transfer intensities across the ASEAN economies vary substantially, with Singapore leading among the four selected economies, followed by Malaysia, Thailand, and Indonesia. The intensities of foreign direct investment (FDI) inflows into the region is closely related to the levels of technology transfer to the region. It is observed that the Asian financial crisis did alter the concentration of FDI inflows in these countries. The data also show that the ratios suffered a setback in the year after 1998. After this setback, both Malaysia and Singapore gained momentum again in attracting inflows of FDI, almost double the ratio of 1998. This indicates that Malaysia and Singapore were the most successful among the selected ASEAN countries in tapping the benefits of FDI and technological transfers with good strategies and policies. In contrast, Indonesia faced a continuing outflow of FDI since the crisis, yielding a negative impact on its economic activities. Among nations, Japan and the United States are the two dominant FDI providers for the ASEAN region, and they have contributed substantially in the transfer of technologies into the region.
\end{abstract}

Keyword: Technology transfer, Knowledge spillover, Trade, Foreign direct investment 